\title{
Menggali Filsafat Wayang Beber untuk Mendukung Perkembangan Industri Kreatif Batik Pacitan
}

\author{
Suyanto \\ Institut Seni Indonesia (ISI) Surakarta \\ Jalan Ki Hadjar Dewantara No.19 Kentingan, Jebres, Surakarta 57126
}

\begin{abstract}
The article is entitled 'The Digging Philosophy of Wayang beber for Supporting the Development Batik Pacitan Creative Industry'. It is a juice from the results of my research at the second year. This research was done to see the extent to which conditions of the Wayang Beber Pacitan its relation to growth and development of the economy and industry, also as media strengthening local wisdom and efforts increase the economy of communities in Pacitan.

This research uses Action Research approach through four stages namely determine focus, data collection, analysis and interpretation, and the action field. Methods undertaken through stages of assessment, design, socialization, mentoring and training, production, and Launching.

This is also underlying for research the third year i.e. dissemination draft corporate identity branding guide ecotourism "kampong of batik" and draft training module design the motif reserved for industrial cluster batik craftsmen so able to improve the economy of Pacitan Society.
\end{abstract}

Keywords: philosophy, Wayang Beber, batik motif Pacitan

\begin{abstract}
ABSTRAK
Artikel ini berjudul “Menggali Filsafat Wayang Beber untuk Mendukung Perkembangan Industri Kreatif Batik Pacitan" Ini merupakan perasan dari hasil penelitian pada tahun kedua. Penelitian ini dilakukan untuk melihat sejauh mana kondisi Wayang beber Pacitan hubungannya dengan pertumbuhan dan perkembangan ekonomi dan industri, serta perannya sebagai media penguatan kearifan lokal dan upaya peningkatan perekonomian masyarakat Pacitan.

Penelitian ini menggunakan pendekatan Action Research melalui empat tahapan: menentukan fokus, pengumpulan data, analisis dan interpretasi data, serta tindakan lapangan. Metode yang dilakukan melalui tahap pengkajian, perancangan, sosialisasi, pendampingan dan pelatihan, produksi, serta Launching.

Hasil penelitian tahun kedua ini menjadi acuan penelitian tahun ketiga untuk: desiminasi draft corporate identity branding panduan ekowisata kampung batik dan draft modul pelatihan perancangan desain motif batik yang diperuntukkan bagi pengrajin klaster industri batik Pacitan sehingga mampu meningkatkan perekonomian masyarakat Kabupaten Pacitan.
\end{abstract}

Kata kunci: filsafat, Wayang Beber, motif batik Pacitan 


\section{PENDAHULUAN}

Pacitan merupakan salah satu dari 38 kabupaten di Jawa Timur, terletak di sebelah barat daya, di antara $110^{\circ} 55^{\prime}-111^{\circ} 25^{\prime}$ Bujur Timur dan 7055'- 8ำ17' Lintang Selatan, dengan luas wilayah $1.389,8716 \mathrm{Km}^{2}$ atau 138.987,16 Ha. Wilayah tersebut sebagian besar berupa perbukitan yaitu kurang lebih $85 \%$, gunung-gunung kecil kurang lebih 300 buah menyebar diseluruh wilayah Kabupaten Pacitan dan jurang terjal yang termasuk ke dalam deretan Pegunungan Seribu yang membujur sepanjang selatan Pulau Jawa, sedang selebihnya merupakan dataran rendah. Bila ditinjau dari struktur dan jenis tanah, Pacitan terdiri dari Assosiasi Litosol Mediteran Merah, Aluvial kelabu endapan liat, Litosol campuran Tuf dengan Vulkan serta komplek Litosol Kemerahan yang ternyata di dalamnya banyak mengandung potensi bahan galian mineral.

Kabupaten Pacitan terletak di Pantai Selatan Pulau Jawa dan berbatasan dengan Propinsi Jawa Tengah dan daerah Istimewa Jogyakarta merupakan pintu gerbang bagian barat dari Jawa Timur dengan kondisi fisik Pegunungan Kapur selatan yang membujur dari Gunung Kidul ke Kabupaten Trenggalek menghadap ke Samudera Indonesia. Adapun wilayah administrasi terdiri dari dari 12 Kecamatan, 5 kelurahan dan 166 desa, dengan letak geografis berada an-

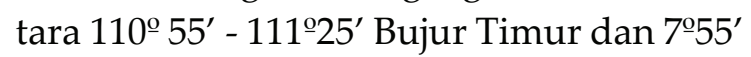
- 81ํㄱ' Lintang Selatan. Kabupaten Pacitan mempunyai batas-batas administrasi, sebelah timur Kabupaten Trenggalek, sebelah selatan Samudera Indonesia, sebelah barat Kabupaten Wonogiri (Jawa Tengah), sebelah utara Kabupaten Ponorogo (Jawa Timur). Adapun tanah yang ada di wilayah Kabupaten Pacitan sebagian besar terdiri dari tanah ladang 21,51\% atau 29.890,58 ha, poemukiman penduduk $02,27 \%$ atau $3.153,33$ ha, hutan $58,56 \%$ atau 81.397 ha, sawah $09,36 \%$ atau $13.014,26$ ha, pesisir dan tanah kosong $08,29 \%$ atau $11.530,99$ ha.
Jumlah industri yang ada di Kabupaten Pacitan tahun 2011, baik industri besar, industri sedang maupun industri kecil adalah 10.192 unit industri di Kabupaten Pacitan sudah mulai mengalami perkembangan dibandingkan tahun-tahun sebelumnya. Sektor industri mempunyai peranan strategi untuk mendukung pertumbuhan ekonomi, meningkatnya produktivitas, masyarakat, menciptakan lapangan usaha, memperluas lapangan kerja serta meningkatnya pendapatan masyarakat. Kegiatan sektor industri di Kabupaten Pacitan masih tergolong skala menengah dan kecil, khusus industri kecil yang merupakan industri rumah tangga dan dilakukan oleh kelompok masyarakat serta merupakan kegiatan sampingan. Kegiatan ini berbasis di pedesaan. Dalam perkembangannya, sektor ini mulai berorientasi pada kegiatan ekspor, baik tingkat regional, nasional maupun internasional. Beberapa komoditi industri kecil tersebut antara lain anyaman bambu, mainan anak (toys), batu mulia, gerabah seni, batik tulis telah mampu menembus pasar ekspor.

Potensi pariwisata di Kabupaten Pacitan meliputi wisata pantai, wisata goa, wisata budaya/ religius, wisata rekrekeasi, wisata industri. Potensi objek wisata dikembangkan melalui Program Pembangunan Kepariwisataan mencakup kegiatan peningkatan dan rehabilitasi objek wisata yang ada, peningkatan sarana dan prasarana ke lokasi objek wisata, pengelolaan objek wisata berupa menggalang kerja sama dengan biro perjalanan dan perhotelan, penataan manajerial perhotelan dan rumah makan serta kegiatan promosi.

Objek-objek wisata di Kabupaten Pacitan dapat diklasifikasikan menjadi beberapa kategori antara lain: 1. Objek wisata yang sudah dibangun dan telah memberikan kontribusi bagi pendapatan masyarakat dan daerah, seperti: Pantai Teleng Ria, Pantai Tamperan, Goa Gong, Goa Tabuhan, 
Pemandian air hangat dan Pantai Srau. 2. Objek wisata yang mempunyai prospek yang baik yang perlu penanganan dan pembangunan yang konseptual seperti: Pantai Klayar, Pantai Watukarung, Pantai Srau, Pantai Sidomulyo, Luweng Jaran dan Luweng Ombo serta kegiatan atraksi wisata seperti: Ceprotan, Tari Khetek Ogleng dan Monumen Panglima Besar Jenderal Sudirman. 3. Objek wisata lainnya yang menjadi wahana pelengkap kepariwisataan seperti: Goa dan objek wisata sejarah dan sebagainya.

Desa Cokrokembang sebagai salah satu wilayah di Kabupaten Pacitan merupakan daerah penghasil batik yang cukup potensial. Sebagian besar penduduk Desa Cokrokembang, terutama wanita, menjadi pekriya batik. Kegiatan membatik di Desa Cokrokembang sudah ada sejak lama, pembuatan batik tulis di Desa Cokrokembang mulanya merupakan usaha yang dilakukan secara turun temurun dari pendahulu mereka, kemudian usaha batik tulis ini terus berkembang hingga terbentuk sebuah perusahaan batik tulis dengan nama Perusahaan Batik Tulis Puri.

Pada awalnya Perusahaan Batik Tulis Puri hanyalah tempat usaha keluarga yang dijalankan dan dikelola oleh anggota keluarga, tetapi dalam perkembangannya perusahaan ini menjadi tumpuan masyarakat sekitar. Para wanita memiliki lebih banyak waktu luang karena mereka tidak sehari penuh berada di sawah. Oleh karena itu, mereka memilih membatik, baik sebagai pekerjaan sampingan maupun sebagai pekerjaan tetap. Karya batik tulis di Desa Cokrokembang, terutama di Perusahaan Batik Tulis Puri, telah banyak mengalami perkembangan, mulai dari ragam hias, warna, sampai dengan teknik. Umumnya batik Pacitan hanya menggunakan warna terang dan gelap. Warna terang yaitu warna dasar kain (putih), sedangkan warna gelap yaitu warna wedel yang digunakan untuk mewarnai motif hias yang digunakan.
Dilihat dari bentuk secara keseluruhan, ragam hias batik Pacitan merupakan pengembangan dari bentuk tumbuhan dan hewan. Pacitan merupakan daerah pegunungan, hanya sebagian kecil penduduknya yang menjadi nelayan. Sebagian besar penduduk Kabupaten Pacitan adalah petani, maka ragam hias batik yang berkembang adalah tumbuhan dan burung yang sering terlihat di sekitar hunian penduduk.

Motif batik yang diambil tidak saja tumbuhan dan hewan yang hidup di darat, motif hewan dari laut juga ada di motif batik Pacitan. Ada motif binatang ikan yang diatur sedemikian rupa yang saling tumpang tindih, berhimpitan di antara motif-motif ikan yang banyak, namun masih ada ruang yang diberi isian yang berbeda antara satu dengan yang lain agar memberi kesan ruang yang bervariasi. Motif ikan tampak hidup dan bergerak dinamis mengikuti gerakan ikan di air. Motif batik yang disusun seperti teknik lukisan aliran kubisme ini menggunakan pewarna alam yang berasal dari daun mangga dan kulit jambal.

Selain batik, Pacitan juga terkenal dengan wayang bebernya. Wayang Beber Pacitan telah banyak ditulis oleh para peneliti, seperti yang telah dilakukan oleh Petrus Suwaryadi, dkk. (1982), tentang wayang beber di Gunung Kidul dan Pacitan. Primadi Tabrani (1991) telah meninjau Bahasa Rupa wayang beber Jaka Kembang Kuning dari telaah Cara Wimba dan Tata Ungkapan Bahasa Rupa Media Rupa-rungu Dwimatra Modern, dalam hubungannya dengan Bahasa Rupa Gambar Prasejarah, Primitif, Anak dan Relief cerita Lalitavistara Borobudur untuk Disertasi Doktor, Fakultas Pasca Sarjana ITB. Rudhi Prasetyo (2007) meneliti tentang Ragam Tutur dalam Pertunjukan Wayang beber Pacitan. Kemudian penelitian juga dilakukan oleh Luqman Haroni Said (2008) tentang Seni Pertunjukan Wayang beber di Desa Gedompol, Kecamatan Donorojo, Kabupaten Pacitan dalam Telaah Ben- 
tuk, Fungsi, dan Makna. Warto (2012) dari Universitas Sebelas Maret, Wayang Beber Pacitan: Fungsi, Makna, dan Usaha Revitalisasi. Dari sekian banyak penelitian yang telah dilakukan belum ada yang membahas tentang wayang beber dalam hubungannya dengan pemberdayaan masyarakat Pacitan dalam rangka menumbuhkembangkan industri kreatif yang berbasis kearifan lokal.

Di antara berbagai jenis wayang di Indonesia, wayang beber termasuk wayang yang paling unik, sebab mempunyai bentuk pertunjukan yang khusus dengan menampilkan gambar-gambar sebagai objek pertunjukan. Dalam pertunjukan wayang beber, dalang menuturkan cerita dari gambar-gambar tersebut dengan diiringi musik gamelan. Gambargambar dari wayang beber, dilukis sedemikian rupa pada kertas atau kain, dibuat satu adegan menyusul adegan lain secara berurutan dengan menggunakan teknik lukis tradisional yang disebut teknik sungging yang bagus sekali, cermat, teliti serta mempunyai gaya yang spesifik. Ini merupakan aset yang patut dibanggakan oleh masyarakat Pacitan, dan sangat memungkinkan dikembangkan sebagai motif Batik Pacitan.

\section{METODE}

Teori Action Research memiliki empat tahapan, yaitu select a focus, collect data, analyze and interpret data, dan take action sebagaimana diungkapkan oleh Christoper Gordon (1998). Penelitian kekaryaaan seni ini juga menggunakan tinjauan disain dengan pendekatan multidisipliner, dalam prosesnya dirasa kurang mencukupi jika hanya dengan pendekatan yang menekankan pada segi apresiasi (design appreciation) dan penafsiran (design interpretation). Dalam mengkaji desain, termasuk bidang desain, selalu terkandung juga konsekuensi untuk mengkaji aspek sosial, ekonomi, kebudayaan, teknologi, dan psikologi suatu karya (Schari, 2002:2).
Adapun langkah-langkah yang dilakukan dalam beberapa tahapan kegiatan adalah sebagai berikut: 1) tahapan pengkajian, pada tahun pertama dilakukan identifikasi terhadap potensi yang ada di wilayah Pacitan sentra industri batik, dan identifikasi lokasi yang memiliki potensi wisata baik wisata alam maupun seni budaya; 2) tahapan perancangan, pada tahun kedua dilakukan kegiatan: merancang draft panduan desa wisata batik di Pacitan, dan merancang draft modul pelatihan perancangan desain motif batik berbasis figur wayang beber yang diperuntukkan pengrajin klaster industri batik; 3) tahapan sosialisasi, masih dalam tahun ke dua dilakukan sosialisasi sebagai media pengenalan sekaligus untuk mendapatkan umpan balik (feedback) dari segenap lapisan masyarakat yang berkompeten dan berbagai unsur yang terkait dengan draft rancangan panduan desa wisata batik, dan draft modul pelatihan dan pendampingan perancangan desain motif batik kepada pengrajin batik di Pacitan; 4) tahapan pendampingan dan pelatihan, pada tahun ke tiga dengan kegiatan: pendampingan penerapan draft rancangan panduan desa wisata batik, dan pelatihan penerapan draft modul pelatihan dan pendampingan perancangan desain motif batik kepada pengrajin batik di Pacitan; dan 5) tahapan produksi dengan kegiatan: pencetakan draft rancangan panduan desa wisata batik; dan pencetakan draft modul pelatihan perancangan desain motif batik kepada pengrajin batik di Pacitan.

\section{HASIL DAN PEMBAHASAN}

Penelitian tahun kedua ini menghasilkan luaran: 1) terimplementasi pola motif dan prototipe batik dan diversifikasi produk lainnya berbasis figur wayang beber khas Pacitan; (2) diproduksinya prototipe motif batik dan diversifikasi produk lainnya dengan berbasis figur wayang beber sebagai 
ciri khas batik Pacitan; (3) tersusunnya draft corporate identity branding panduan ekowisata kampung batik di Pacitan; (4) tersusunnya draft modul pelatihan perancangan desain motif batik dan diversifikasi produk lainnya berbasis figur wayang beber yang diperuntukkan pengrajin klaster industri batik; (5) tahapan proses HKI atas rancangan desain motif batik berbasis figur wayang beber; (6) telah terbit artikel dalam jurnal ilmiah; dan (7) laporan hasil penelitian.

\section{Wayang Beber Pacitan}

Wayang beber merupakan salah satu jenis wayang yang terdapat di Jawa, terbuat dari kertas panjang, dan digambari (dilukis) episode-episode cerita yang pementasannya berupa pertunjukan gambar yang digelar (Jawa: dibeber) dan tidak berupa bayangan (shadow play) seperti wayang kulit purwa. Wayang beber termasuk pertunjukan teater tutur dengan objek gambar yang dituturkan. Pertunjukan wayang beber dilakukan dengan membawakan narasi cerita (seperti mendongeng) dan peragaan gulungan gambar-gambar yang dibeberkan. Adeganadegan dalam gulungan gambar tersebut melukiskan kejadian-kejadian cerita yang diangkat dari cerita rakyat sekitar kisah asmara Raden Panji Inukertapati dengan Galuh Candrakirana. Rangkaian gambar itu melukiskan urutan adegan dari suatu cerita lakon yang terdiri dari berbagai babak. Setiap babak terdiri atas beberapa adegan yang dilukis di atas gulungan kertas atau kain (Subandi dkk., 2011).

Wayang beber kuno digambarkan di atas kertas gedhog, tetapi wayang beber yang baru dibuat di Mangkunegaran pada tahun 1935 sampai dengan tahun 1939 digambarkan pada lembaran kain mori alus. Pembuatan wayang beber baru di Mangkunegaran adalah atas perintah Kanjeng Gusti Arya Adipati Mangkunegoro VII pada masa berkuasa. Pembuatan ini adalah tedhakan (coppy) dari wayang beber kuno dan yang masih ada, yaitu Wayang beber Pacitan dan Wayang beber Wonosari (Bagyo Hariyono, 2005).

Wayang Beber Pacitan sering disebut oleh masyarakat Karangtalun dan sekitarnya dengan sebutan Wayang Simbah atau juga sering disebut Punden Tawangalun, sedangkan pemiliknya memberi sebutan Wayang Beber Jaka Kembang Kuning, sebagai sebutan nama lakonnya. Isi lakon Jaka Kembang Kuning adalah kisah percintaan antara Raden Panji Inukertapati dan Dewi Sekartaji dari Kediri. Kisah ini merupakan salah satu versi cerita Panji dari sejumlah kisah Panji yang dikenal masyarakat. Masyarakat pendukungnya lebih mengenal jenis wayang ini dengan sebutan Wayang beber Paci$\tan$ (Subandi, dkk., 2011).

Wayang beber Karang Talun Pacitan dalam ceritanya mempunyai delapan tokoh, yaitu: Raden Jaka Kembang Kuning (Panji), Dewi Sekartaji, Prabu Brawijaya (Lembu Hamijaya), Prabu Klana Sewandana, Patih Kebolorodan, Ki Tawangalun, Ki Naladerma, Raden Gandarepa, Dewi Kili Wanu Saba (Kilisuci), Ki Tumenggung Kalamisani, Nyi Temunggung Cona-Cani, Ki Demang Kuning, mBok Mindoko, dan mBok Tegaron.

Dilihat dari nama-nama tokoh yang ada itu memang jumlahnya sangat terbatas, hal ini dimungkinkan karena wayang beber ini merupakan wayang dalam bentuk lukisan tidak bergerak yang melekat pada lembaran kertas. Pada tiap-tiap episode (jagong) jelas tidak mungkin dikurangi atau pun ditambah penampilan tokohnya, dengan demikian ruang penceritaan dan penampilan tokoh dibatasi oleh ruang lukisan yang ada. Meskipun demikian, keterbatasan jumlah tokoh dalam wayang beber bukanlah hal yang penting dalam revitalisasi peran wayang beber ini. Hal yang lebih penting adalah wayang beber mampu menginspirasi pengembangan motif batik karena memiliki unsur-unsur yang menarik dan sangat memungkinkan untuk dikembangkan dalam 
motif Batik Pacitan. Unsur-unsur itu antara lain yaitu bentuk lukisan wayang, ragam lukisan latar, dan skadi warna. Semua unsur tersebut memiliki bentuk dan warna yang khas tidak terdapat dalam lukisan wayang lainnya. Jadi wayang beber ini sangat memungkinkan jika digunakan sebagai kekhasan motif Batik Pacitan.

\section{Kondisi Wayang Beber Pacitan Sekarang}

Wayang beber merupakan salah satu bentuk kesenian tradisional Jawa yang langka. Hingga sekarang wayang beber yang dikenal hanya dimiliki oleh dua tempat, yaitu Desa Donorojo Pacitan Jawa Timur dan Desa Wonosari Gunung Kidul Yogyakarta. Wayang beber memang sangat berbeda dengan wayang kulit (purwa) yang sudah banyak dikaji dan ditulis, baik oleh para peneliti dari dalam maupun para peneliti dari luar negeri. Akibatnya wayang beber ini tidak begitu dikenal oleh masyarakat luas, karena kurangnya informasi dan terbatasnya literatur yang memuat tentang wayang beber. Sekarang wayang beber sangat jarang dipergelarkan, karena selain memiliki penggemar yang sangat terbatas dan relatif tidak dikenal oleh masyarakat. Unsur-unsur magis yang melekat pada wayang beber dalam beberapa segi justru menjadi kendala untuk memperkenalkannya kepada kalayak luas. Meskipun demikian, dengan berbagai keunikannya, wayang beber tetap merupakan salah satu aset budaya bangsa Indonesia yang mencerminkan jati diri bangsa yang bernilai tinggi. Seni wayang beber merupakan perpaduan dari berbagai unsur seni, antara lain: seni lukis, seni suara, seni sastra, seni pentas, dan seni musik, yang satu sama lainnya saling mendukung.

Seperti halnya seni tradisi wayang pada umumnya, wayang beber selain mengandung nilai-nilai kehidupan yang penting untuk dipelajari, juga dapat digunakan sebagai sumber inspirasi bagi generasi muda dalam menghadapi tantangan zaman. Wayang Beber Pacitan sudah menjadi bagian dari budaya tradisi masyarakat, wayang beber juga sebagai bagian dari identitas masyarakat lokal yang berakar kuat dalam tradisi mereka. Sebagai aset budaya, wayang beber perlu diwariskan kepada generasi muda dalam rangka memperkokoh jati diri dan ketahanan budaya bangsa di tengah-tengah gempuran budaya global. Salah satu dampak era globalisasi adalah makin terdesaknya masyarakat lokal dengan kekayaan budaya yang dimilikinya. Bersamaan dengan semakin memudarnya ikatan tradisi mereka, banyak kekayaan budaya lokal terdesak atau bahkan punah akibat desakan budaya asing. Masyarakat tradisi kehilangan identitasnya karena tercerabut dari akar budayanya (Warto, 2012:57).

Ditinjau dari aspek pertunjukannya, wayang beber mengalami nasib yang sama seperti kesenian tradisi lainnya, "hidup enggan mati pun tak mau". Khususnya Wayang beber Pacitan memang spesifik keberadaannya. Selain tidak adanya regenerasi dalang yang representatif, juga ikatan keyakinan keluarga pemiliknya terhadap mitos wayang beber itu sendiri sangat berpengaruh terhadap kehidupan Wayang Beber Pacitan. Kendatipun demikian, campur tangan dari pemamangku kebudayaan juga sangat berpengaruh terhadap keberadaan wayang beber ini. Hampir setiap peneliti menyoroti dan mengungkapkan komentar yang sama, bahwa terjadi fenomena yang cukup ironis, ketika banyak bangsa lain melakukan penelitian, bahkan lembaga dunia seperti UNESCO memberikan apresiasi tinggi terhadap segala bentuk kearifan lokal, seperti halnya wayang mendapatkan pengakuan sebagai warisan budaya dunia oleh UNESCO pada pada tahun 2003, tetapi justru masyarakat pemangku kebudayaan itu sendiri kurang peduli terhadap kekayaan budaya yang dimiliki. Hal demikian inilah di anta- 
ranya yang menjadi penyebab banyaknya aset budaya lokal yang bernilai tinggi semakin surut dan akhirnya punah.

Di dalam forum serawung antarbangsa, bukan berarti kita saling larut antara bangsa dan budaya satu dengan yang lain, melainkan justru saling menunjukkan jati diri masing-masing. Contoh, ketika orang Amerika datang ke Indonesia, tidak mungkin mereka menanyakan atau minta diajari tari balet atau lagu-lagu pop Barat, tetapi tari tradisi Jawa, Minang, Bali atau pun Dayak. Global dan lokal bukan suatu zaman yang identik dengan pertentangan/konflik, tetapi bergantung pada cara kita menyikapi.

Sebagaimana diharapkan oleh Warto (2012), keunikan wayang beber yang tidak ditemukan di dalam kebudayaan bangsa lain dimungkinkan akan menjadi media untuk saling memahami dalam komunikasi antarbangsa atau antarumat manusia. Memang melalui kesenian (wayang), saling pengertian antar manusia yang mempunyai latar belakang budaya berbeda dimungkinkan dapat dibangun secara komprehensif. Akan tetapi satu hal yang menjadi kendala bahwa sekarang keadaan wayang beber tidak sesubur wayang kulit purwa, bahkan boleh dikatakan hampir punah, baik ditinjau dari wujud fisik wayang maupun ditinjau dari regenerasi dalang wayang beber yang mampu menjajikan cerita dan menyampaikan makna, pesan serta nilai-nilai yang terkandung di dalam lukisan wayang beber itu.

Di Pacitan hanya terdapat satu-satunya perangkat wayang beber yang masih hidup, yaitu di Desa Gedompol Kecamatan Donorojo Kabupaten Pacitan Jawa Timur, yang sekarang telah dibuat replikanya oleh Rudy Prasetyo, seorang murid dari Ki Mardi, dalang Wayang beber Pacitan, yang sekarang selain sebagai dalang juga sebagai guru di SMK I Pacitan. Dalam usaha melestarikan keberadaan Wayang Beber Pacitan ini, Rudy mengajarkan pula menggambar wayang beber kepada anak-anak SMP dan SMK di
Kota Pacitan. Langkah-langkah pengenalan wayang beber terhadap masyarakat yang telah dilakukan oleh Rudy Prasetyo ini kiranya perlu mendapat dukungan dari berbagai pihak, terutama dari pihak Pemerintah Daerah Pacitan sendiri, agar secara menyeluruh masyarakat Pacitan memiliki kebanggaan lokal yang sangat berharga ini.

Mengingat posisi wayang beber dalam dunia pertunjukan sekarang kemungkinan memang sulit dikembangkan, tetapi bukan berarti punah, eksistensinya tidaklah harus selalu dalam bentuk pertunjukan. Wayang beber dapat mengambil posisi lain dalam pengembangan seni budaya Pacitan. Selain dapat dikembangkan sebagai bentuk hiasan atau lukisan dinding, tentunya dapat dihadirkan pula dalam pengembangan motif Batik Pacitan, juga dalam bentukbentuk suvenir wisata lainnya.

\section{Kandungan Nilai Filsafati dalam Wayang Beber}

Sebagaimana telah diproklamasikan oleh UNESCO pada 7 Nopember 2003, wayang diakui sebagai salah satu warisan budaya dunia tak benda (UNESCO, 2003:2). Kata wayang dalam hal ini tidak hanya terbatas pada wayang dengan segala bentuk pertunjukannya yang secara umum masih eksis dalam masyarakat, tetapi meliputi segala macam bentuk wayang yang ada di bumi Indonesia inilah yang mendapatkan penghargaan atas kandungan nilai-nilai filosofinya yang dipandang edipeni dan adiluhung. Wayang tidak hanya tontonan yang indah, tetapi juga sebagai tuntunan yang mengandung ajaran moral keutamaan hidup (Solichin, Suyanto, 2014:19).

Penelitian ini mengupas tentang kandungan nilai-nilai filsafati dalam wayang, terutama hal-ikhwal yang berhubungan dengan Wayang beber Pacitan, mencakup pesan etika dan estetika. Penelitian ini diharapkan dapat membuka pandangan masyarakat dan memberikan bekal pengeta- 
huan mengenai pengertian nilai etika dan estetika dalam pertunjukan wayang beber; terutama bagi khalayak umum yang peduli wayang. Pemahaman tentang hal ini pada gilirannya diharapkan akan mampu mengantar para pemerhati wayang untuk lebih memahami dan menyadari betapa pentingnya nilai-nilai dalam pertunjukan wayang itu bagi kemaslahatan manusia.

Pertunjukan wayang merupakan eksplorasi dari nilai-nilai yang berhubungan dengan kehidupan dan kebudayaan manusia. Nilai-nilai itu disampaikan melalui pembeberan peristiwa yang berupa simbol-simbol dalam pertunjukan. Simbolsimbol itu dapat berupa tokoh, misalnya tokoh ksatria, raksasa, dewa, binatang, dan sebagainya; juga berupa ungkapan bahasa dalam bentuk dialog tokoh dan narasi dalang. Dipandang dari aspek epistemologis, ungkapan simbol-simbol dalam pertunjukan wayang itu mengandung pesan-pesan hakikat pengetahuan ataupun ajaran-ajaran kehidupan. Dengan kata lain, wayang merupakan salah satu sumber pengetahuan hidup (kawruhing urip). Dengan demikian, untuk mencapai kebenaran mendasar mengenai pemahaman nilai dalam pertunjukan wayang terlebih dahulu harus memahami hakikat nilai dan pengetahuan yang terkandung dalam wayang.

Pertunjukan wayang menggelarkan secara luas mengenai hakikat kehidupan manusia dan alam di sekitarnya serta rahasia hidup beserta kehidupan manusia. Melalui pertunjukan wayang, manusia diseyogyakan merenungkan hidup dan kehidupan ini, utamanya mengenai kehidupan pribadi yang berhubungan dengan sangkan paraning dumadi dan apa yang dapat dilakukan dalam menghadapi kehidupan di dunia yang tidak lama ini. Pendapat Sarsita yang dikutip oleh Sena Sastra Amidjaja (1964) menyatakan bahwa, setiap pertunjukan wayang pada dasarnya merupakan lambang perjuangan batin dengan berkompe- tisi antara prinsip baik dan prinsip buruk di dalam kehidupan manusia pada umumnya, atau dengan istilah lain antara mistik dan magis. Pertunjukan wayang kulit terdiri dari berbagai adegan yang saling berhubungan erat antara satu dengan lainnya. Setiap adegan melambangkan fase tertentu dari kehidupan manusia, dan keberadaan fase-fase itu bersifat abadi. Akan tetapi dengan sengaja ataupun tidak, hal itu selalu diselubungi dengan kabut mistik, agama, buah fantasi penciptanya, yang kemungkinan sangat tebal keberadaannya. Apabila dianalisis secara seksama, perbandingan itu akan tampak nyata. Oleh karena itu, hampir senantiasa dapat ditemukan kembali unsur-unsur secara terurai yang membentuk susunan ketasawufan sepanjang waktu itu.

Masyarakat Nusantara pada umumnya menjunjung tinggi moralitas dan religiusitas. Maka menjadi sangat tepat kalau wayang dijadikan cermin pembelajaran hidup yang disesuaikan dengan prinsip dasar masayarakat itu sendiri. Wayang merupakan pertunjukan tradisional yang sarat akan pesan moral dan nilai-nilai kehidupan yang dapat dijadikan sarana pendidikan budi pekerti luhur, yang efektif bagi anak-anak serta bagi generasi muda bangsa, karena pada dasarnya di dalam pertunjukan wayang terdapat ajaran moral dalam bentuk sanépa, piwulang, pranatan, wursita, wewaler, pepacuh ataupun pituduh untuk mencapai kehidupaan yang ideal sesuai dengan wewaton yang digariskan oleh masyarakat pada umumnya.

Pertunjukan wayang dengan segala perabot dan medium yang ada di dalamnya merupakan simbol-simbol kehidupan. Simbol-simbol itu di antaranya berupa profil boneka wayang, tata panggung yang berupa bentuk tata dekoratif wayang (simpingan kanan dan kiri), serta ditancapkan sebuah wayang kayon di tengah-tengah kelir, yang semuanya merupakan aplikasi sim- 
bol transendental-vertikal dan horisontal yang berhubungan dengan pola perilaku manusia dalam masyarakat. Sedangkan pada lakon-lakon wayang terkandung unsur-unsur mistik, cinta kasih, keberanian, kepahlawanan, semua merupakan simbol-simbol hayatan yang tersamar melalui bayang-bayang wayang dalam bingkai dramaturgi yang dilakonkan oleh dalang terhadap boneka-boneka wayangnya. Fungsi simbol tersebut merupakan fungsi dari imanen-horisontal (sebagai wahana komunikasi berdasarkan konteksnya dan perekat hubungan solidaritas masyarakat pendukungnya). Hal ini membuktikan bahwa wayang merupakan dunia simbol, hanya mereka yang "lantip rasa" yang bisa mengurai simbol beserta maknanya di balik kenyataan kelir yang disebut "kasunyatan".

Memahami simbol pada dasarnya adalah memahami masalah makna, dan nilai filosofis yang diyakini oleh sekelompok masyarakat pendukungnya, kemudian menjadi acuan dan pedoman bagi kehidupan masyarakat tersebut. Hal demikian sangat berkaitan dengan pertunjukan wayang yang sarat akan simbol-simbol dan pemaknaan, serta adanya cara pandang budaya Jawa sangat kental di dalamnya. Maka wayang merupakan bagian simbol dari dunia Jawa yang lebih menerangkan bahwa pandangan Jawa dalam melihat, memahami, dan berperilaku serta berbudi pekerti juga berorientasi terhadap budaya sumber, di mana proses budaya Jawa selaras dengan dinamika masyarakat yang mengacu pada konsep budaya induk, yaitu sangkan paraning dumadi (Geertz, 1993:X-XII).

Dengan demikian, pertunjukan wayang dipandang sebagai bahasa simbol dari kehidupan yang lebih bersifat rohaniah daripada lahiriah. Maka bagi masyarakat pecinta wayang, pertunjukan wayang digunakan sebagai pedoman sikap dan perbuatan, sebagaimana cara pandang mengenai hakekat kehidupan, asal dan tujuan hidup, hubungan manusia dan Tuhan, manusia dengan manusia, serta manusia dengan alamnya (Soetarno, 2005:XVIII-2). Hal-hal tersebut yang menyebabkan para penghayat wayang rela mengapresiasi pertunjukan wayang dengan sunguh-sungguh, mendengarkan semua ungkapan wacana dalang, menyerap semua sari pati ajaran yang dimanifestasikan dalam pertunjukan wayang dengan durasi semalam suntuk.

\section{Edipeni dan Adiluhung}

Konsep Edi adalah pencitraan dari sikap yang ditangkap melalui penghayatan rasa. Yaitu tekait dengan etika dan moralitas yang berkaitan dengan aspek 'Bener' dan Pener serta didasarkan dengan sikap religius tercermin pada Peni, sifat ke arah Edi lebih condong pada maskulinitas, seperti mengarah pada perwujudan yang 'bagus' atau besus, cakrak, cakrik, atau rengguh. Menghayati karakter-karakter yang gagah, kuat, dan tekanan suara yang rendah dan mantap. Maka dari ki dalang dalam memainkan wayang diperlukan suatu ketrampilan yang membuat penonton terpesona.

Konsep Peni adalah citraan estetik yang menunjukkan antara wujud, sikap, dan nilai intrinsik (konseptual, intelektualitas, dan religius) maka seringkali digabungkan menjadi Edi-peni. Suryono memahami Endah, Elok, Edipeni, dan Peni sebagai berikut, Endah berarti indah yang memikat, Elok berarti bagus yang menawan, Edipeni berarti indah yang mempesona atau biasanya diartikan indah yang luar biasa, Peni berarti indah yang berharga (Suryono, 2006:119,212).

Adi dalam bahasa Jawa dapat diartikan sebagai citraan kualitas yang berhubungan dengan moral, karakter, dan kepribadian. Sedangkan luhung sama dengan luhur, dapat diartikan sebagai citraan status atau strata nilai dalam kehidupan. Konsepkonsep demikian merupakan akumulasi dari rasa hayatan yang mendasari manusia 
untuk merenungi sebuah kehidupan yang tergelar dalam pertunjukan wayang.

\section{Simbolisasi Etika dan Estetika dalam Wayang Beber}

Wayang merupakan simbolisasi tentang etika dan estetika. Aspek Etika, dapat dicontohkan dalam kisah Jaka Kembang Kuning dan Dewi Sekartaji, tergambarkan dengan jelas tentang tingkah laku manusia, melalui tokoh-tokoh protagonis dan antagonis yang menggambarkan watak baik dan buruk. Akan tetapi masalah baik dan buruk merupakan akibat dari perbuatan, gagasan dan tujuan yang dicapai oleh masing-masing individu. Aspek etika yang ditandai dengan laku susila untuk mencapai kesempurnaan hanya akan terwujud bila dilandasi oleh keharmonisan segi lahir dan segi batin (Sedyawati dalam Soetarno, 2005:XVII-8). Seperti dimaksud Soetarno di atas, bahwa laku susila menjadi tampak ketika adanya keselarasan dan harmonisasi antara lahir dan batin. Bertemunya Panji Inukartapati yang menyamar sebagai Jaka Kembang Kuning dan Dewi Sekartaji yang menyamar sebagai gadis desa, itu sebagai simbol keharmonisan lahir dan batin.

Aspek estetika tercermin dalam sistem klasifikasi. Di dalam budaya Jawa ditemukan adanya sistem klasifikasi. Dalam gagasan ini komunikasi masyarakat Jawa terlihat sebagai suatu bagian yang lebih besar, kesatuan yang lebih tinggi, dan nasib manusia terkait dengan semua bentuk, pengaruh, dan kejadian yang tidak dapat dinilai dengan konsep secara rasional sekalipun. Wayang sebagai seni pertunjukan tidak lepas dari filsafat keindahan atau estetika. Hakikat dari seni pertunjukan adalah buah karya budaya manusia yang merupakan manifestasi dari nilai-nilai keindahan. Keindahan itulah yang membuat manusia merasa senang dan bahagia. Kendatipun hingga sekarang belum didapatkan jawabannya, bagaimana proses terjadinya manu- sia memiliki rasa keindahan, apakah itu memang merupakan takdir, atau sebagai unsur bawaan hidup, tentu hal tersebut merupakan karunia agung dari sang Pencipta.

Keindahan dalam seni pertunjukan wayang meliputi seluruh kandungan nilai yang tersirat di dalamnya. Maka pengertian indah dalam pertunjukan wayang mempunyai lingkup pengertian sangat luas. Indah tidak berarti hanya tampilan tokoh wayang yang bagus, halus, rumit, berwarna-warni; atau suara gamelan yang mengalun disertai nyanyian suarawati yang merdu saja, tetapi hal yang lebih penting daripada itu adalah pesan-pesan yang disampaikan oleh dalang dalam bentuk sajian secara utuh, baik ungkapan tentang kebenaran, kejahatan, kegembiraan maupun kesusahan, yang mampu menyentuh hati para penonton atau penghayatnya.

Wayang sebagai seni pertunjukan menawarkan sejumlah jalan keluar atas berbagai permasalahan hidup manusia. Keindahan dalam wayang meliputi seluruh kandungan nilai yang tersirat di dalamnya. Dengan demikian pengertian indah dalam pertunjukan wayang mempunyai lingkup pengertian sangat luas.

\section{Revitalisasi Wayang Beber dalam Perkembangan Industri Pariwisata Kreatif}

Wayang beber menyimpan nilai-nilai kearifan lokal yang mampu menjadi sumber inspirasi bagi masyarakat Pacitan untuk menumbuhkembangkan kreativitas dalam memperkaya produk kebudayaan lokal untuk bersaing dalam dunia global. Dalam konteks ini, dipandang perlu dilakukannya revitalisasi wayang beber yang didukung oleh semua pihak agar kesenian tersebut mampu memberi kontribusi dalam pengembangan seni-budaya bangsa.

Pengembangan industri pariwisata dengan berbasis kekayaan lokal sudah selayaknya digalakkan. Hal ini di samping mengangkat kekayaan dan kearifan lokal yang ada, 
juga mengembangkan pertumbuhan ekonomi kreatif dalam rangka meningkatkan kesejahteraan masyarakat. Lebih dari itu, juga membeikan peluang baru pada kehidupan seni tradisi untuk beradaptasi dengan terjadinya perubahan sosial agar tetap lestari dan berkembang. Dalam hal ini sudah barang tentu bahwa bentuk-bentuk kemasan seni tradisi itu harus disesuaikan dengan minat para wisatawan dengan tidak menghilangkan ciri khasnya yang merupakan identitas lokal.

Kehidupan wayang beber di era perkembangan wisata budaya ini kiranya tidak selalu dan harus muncul dalam bentuk seni pertunjukan. Wayang beber sangat memungkinkan berkembang dalam bentuk lukisan, karena pada dasarnya merupakan bentuk lukisan wayang bertema. Sekarang telah dirintis melalui siswa siswi SLTP/SLTA melukis wayang beber dalam bentuk lukisan dekoratif dengan berbagai variasi. Melihat perkembangan itu, sangat memungkinkan lukisan tokoh-tokoh wayang beber itu digarap dalam bentuk-bentuk inovasi lain seperti motif-motif batik kain panjang, sarung, ataupun bahan-bahan kemeja.

Berbarengan dengan penelitian ini berjalan, Pemerintah Kabupaten Pacitan sedang berusaha mencari alternatif pengembangan motif batik khas Pacitan. Selama ini motif batik khas Pacitan hanya berkutat pada motif daun dan buah pace (buah mengkudu), yang didasarkan pada asalusul nama kota Pacitan konon berasal dari dua kosa kata pace-wetan. Dengan munculnya ide penelitian ini, Pemerintah Kabupaten Pacitan telah merespon secara positif, wayang beber ini diharapkan menjadi ikon budaya dan pariwisata serta sebagai salah satu basis pengembangan motif batik khas Pacitan. Program ini direalisasikan dalam tahun 2015-2016 oleh Pemerintah Kabupaten Pacitan bekerja sama dengan Institut Seni Indonesia (ISI) Surakarta.

Sektor pariwisata di Kabupaten Pacitan mempunyai peluang yang cukup prospektif untuk dikembangkan menjadi industri pariwisata yang mampu bersaing dengan pariwisata di daerah yang lain bahkan manca negara, ini cukup beralasan, karena objek wisata yang ada cukup beragam dan mempunyai ciri khusus dan nilai lebih dibanding dengan daerah lainnya. Pengembangan kepariwisataan tidak hanya mampu meningkatkan pendapatan asli daerah semata, yang lebih penting kepariwisataan di Kabupaten Pacitan mampu memberdayakan masyarakat sendiri sehingga mereka merasa memiliki, melaksanakan, melestarikan, dan pada gilirannya dapat meningkatkan pendapatan masyarakat melaui cara memberikan lapangan kerja dan kesempatan berusaha.

\section{SIMPULAN}

Wayang beber Pacitan yang selama ini dapat dikatakan 'terancam punah', bagaimanapun perlu dipikirkan pelestariannya, karena ini merupakan salah satu aset budaya yang tak terhingga nilainya. Oleh karena itu, perlu dilakukan langkah nyata untuk merevitalisasi melalui berbagai usaha, agar Wayang beber Pacitan ini tetap eksis dan menjadi kebanggaan masyarakat Pacitan.

Revitalisasi Wayang beber Pacitan dimungkinkan tidak banyak mengalami hambatan karena keberadaannya yang konon oleh masyarakat Desa Gedompol dikeramatkan dan tidak dapat dibuka setiap saat itu sekarang sudah ada replikanya yang telah dibuat oleh Edy Prasetyo, sehingga wayang beber itu sekarang lebih mudah diamati dan dapat dibuka sewaktu-waktu diperlukan. Selain itu, masyarakat Pacitan pada umumnya telah menyadari bahwa wayang beber merupakan salah satu aset budaya masyarakat yang perlu dilestarikembangkan. Wayang beber bukan hanya milik perorangan ataupun keluarga melainkan menjadi milik masyarakat Pacitan (Edy Prasetyo, wawancara 10 April 2015). 
Dengan munculnya kesadaran masyarakat terhadap pelestarian dan pengembangan Wayang beber Pacitan, serta komitmen Pemerintah Kabupaten Pacitan untuk mendukung kegiatan revitalisasi wayang beber ini sangat dimungkinkan pengembangan produk wisata melalui pengembangan motif batik yang berbasis lukisan wayang beber ini akan segera dapat terrealisasi sesuai dengan yang diharapkan.

\section{Daftar Pustaka}

Abdullah Ciptopawiro

1986 Filsafat Jawa. Jakarta: Balai Pustaka.

Bagyo Hariyono

2005 Wayang beber Pacitan dan Wayang beber Wonosari. Surakarta: ISI Press.

E. Sumaryono

1999 Hermeneutik Sebuah Metode Filsafat. Yogyakarta: Kanisius.

Geertz, Clifford

1993 Abangan, Santri, Priyayi dalam Masyarakat Jawa. Jogyakarta: Kanisius.

Lorens Bagus

2005 Kamus Filsafat. Jakarta: PT. Gramedia Pustaka Utama.

Samsunu Yuli Nugroho

2005 Semar \& Filsafat Ketuhanan. Jogjakarta: Gelombang Pasang.

Sena Sastra Amidjaja

1964 Renungan Pertunjukan Wayang Kulit. Jakarta: Kinta.

Soetarno

1990 Wayang Kulit Perubahan Makna Ritual dan Hiburan. Surakarta: STSI Press.
$---$

2005 Pertunjukan Wayang dan Makna Simbolik. Surakarta: STSI Press.

Solichin \& Suyanto

2011 Pendidikan Budi Pekerti dalam Pertunjukan Wayang. Jakarta: Yayasan SENAWANGI.

2014 Cakrawala Wayang Indonesia. Jakarta: Yayasan SENAWANGI.

Sri Mulyana

1975 Wayang Asal-Usul Filsafat dan Masa Depannya. Jakarta: Alda.

Subandi, dkk.

2011 Wayang Beber Remeng Mangunjaya Gelaran Wonosari dan Wayang Beber Jaka Kembang Kuning Karang talun Pacitan Serta Persebarannya di Seputar Surakarta. Surakarta: ISI Press.

\section{UNESCO}

2004 Wayang Indonesia Performance. Livret Program Book. Jakarta: SENAWANGI \& PT Gramedia.

Warto

2012 Wayang Beber Pacitan: "Fungsi, makna, dan Usaha Revitalisasi", dalam Jurnal Paramita Vol. 22 No. 1.

Webtografi:

Gordon, Christopher

1998 Step in Action Research http://www. stcoll.edu.jm/Education/PDF\%5C Reflective\%20Practicum\%5Csteps_ in_action_research.pdf 